\title{
Immunocytochemical and ultrastructural identification of mitotic cells in the pituitary gland of ovariectomized rats
}

\author{
P. F. Smith and D. A. Keefer \\ Department of Anatomy, University of Virginia Medical School, Charlottesville, \\ Virginia 22908, U.S.A.
}

\begin{abstract}
Summary. Light microscopic immunocytochemistry was utilized on plasticembedded, acrolein-fixed pituitary glands from intact rats and rats killed 14 days after ovariectomy to determine which cell types were undergoing cell division. A significant increase in the number of cell divisions in anterior pituitary cells was seen in ovariectomized rats compared to intact controls. Most of the dividing cells in ovariectomized rats were immunocytochemically identified as gonadotrophs, but dividing somatotrophs and non-immunoreactive cells were also found. All of the dividing gonadotrophs stained with both anti-FSH $\beta$ and anti-LH $\beta$. These cells were large and ovoid with plentiful vesiculated rough endoplasmic reticulum and a single population of granules with a mean diameter of $200 \mathrm{~nm}$. Many of the dividing cells which were not immunoreactive with any of the antisera employed contained small granules, $100 \mathrm{~nm}$ in diameter, but the content of these granules was not determined.
\end{abstract}

\section{Introduction}

After gonadectomy of adult male and female rats the pituitary gonadotroph population exhibits a marked hyperplasia (Yoshimura \& Harumiya, 1965; Ishikawa \& Totsuka, 1968). The source of this increase in cell number has not been well defined. Yoshimura \& Harumiya (1965) postulated that this increase came from a transformation of other cell types, most probably thyrotrophs or follicular cells. However, using tritiated thymidine labelling, Hymer, Mastro \& Griswold (1970) and Stadtler, Stöcker, Dhom \& Tietze (1970) demonstrated increased DNA synthesis in rat pituitaries after gonadectomy, indicating that perhaps increased cell division might play a role in hyperplasia of gonadotrophs.

Up to $80 \%$ of the mitotic activity in pituitary glands of intact male and female rats has been ascribed to cells identified as chromophobes by their tinctorial staining characteristics (Pomerat, 1941 ; Hymer et al., 1970; Kunert-Radek \& Pawlikowski, 1975; Yoshimura, Soji, Kumagai \& Yokoyama, 1977). However, there is some evidence that granular cell types may undergo division after ablation of their target organs (Kurosumi, 1971). After castration or thyroidectomy Kurosumi (1971) demonstrated cells undergoing division which were identified on the basis of their ultrastructural morphology as gonadotrophs or thyrotrophs, respectively. At least two morphologically distinct subpopulations of gonadotrophs have been described in the rat pituitary gland (Kurosumi \& Oota, 1968). Yoshimura et al. (1977) have also described cell types intermediate in ultrastructure between thyrotrophs and gonadotrophs and Moriarty \& Garner (1977), using an immunocytochemical technique, have reported pituitary cells containing both ACTH and FSH $\beta$.

The present study, therefore, was designed to determine (1) whether there is an increase in 
mitosis in the rat pituitary gland after ovariectomy, (2) which cell types divide, and (3) whether any dividing cells contain more than one immunoreactive hormone.

\section{Materials and Methods}

Female Sprague-Dawley white rats were monitored for vaginal opening which occurred on Day 39 or 40 after birth. Vaginal smears were taken every morning between 08:00 h and 09:00 h after vaginal opening by the method of vaginal lavage. Only animals demonstrating 3 consecutive 5-day cycles were used, and 5 control animals were killed on the morning of dioestrus I, while 5 animals were bilaterally ovariectomized on the morning of dioestrus I and killed 14 days later. All animals were killed by decapitation without anaesthesia between 10:00 and 11:00 h. Precautions were taken to ensure that the animals were killed at the same time of day and at the same stage of the oestrous cycle because mitotic activity in the pituitary gland varies with these parameters (Hunt \& Hunt, 1966; Nouet \& Kujas, 1975).

The pituitaries were excised and immersion-fixed in $2 \%$ acrolein in $0.1 \mathrm{M}$-sodium phosphate buffer $\left(\mathrm{pH} \mathrm{7.4)}\right.$ at $4^{\circ} \mathrm{C}$ for approximately $6 \mathrm{~h}$. Following an overnight rinse in phosphate buffer the pituitaries were dehydrated in a graded series of ethanols and embedded in Epon-Araldite. Horizontal $1.0 \mu \mathrm{m}$ thick sections of the pituitary glands were cut on a Sorvall MT2-B ultramicrotome.

Five sets of sections, consisting of seven serial sections each, were collected from each pituitary. In each set one section was stained with azure II/methylene blue while the others were first immunocytochemically stained with antiserum to one of 6 pituitary hormones or their subunits and subsequently counterstained with azure II/methylene blue.

Immunocytochemical method. Sections were collected and heat-mounted onto cleaned glass slides for light microscopy. The sections were etched with an alcoholic sodium hydroxide solution (Baskin, Erlandsen \& Parsons, 1979) and immunocytochemically stained using a modification of the unlabelled antibody-enzyme bridge technique (Mason, Phifer, Spicer, Swallow \& Dreskin, 1969) (see Text-fig. 1). The following antisera, raised in rabbits, were used at the concentrations indicated to stain sets of adjacent sections. All antiserum dilutions were made with $0.01 \mathrm{M}$-sodium phosphate-buffered saline at a $\mathrm{pH}$ of 7.4 containing $1 \%$ normal goat serum and $0.1 \%$ sodium azide.

Anti-rat LH $\beta$ (1:10 000) (AFP 2-11-27), anti-human FSH $\beta$ (3 710 194) (1:1000), anti-rat TSH $\beta$ (AFP 1-19-15) (1:5000) and anti-rat prolactin (no code) (1:10 000) were generously supplied by Dr A. F. Parlow, NIAMDD, NIH, Bethesda, Maryland. Anti-bovine GH (\#20P) (1:2500) was donated by Dr Peter Petrusz, University of North Carolina, Chapel Hill, North Carolina. Anti-porcine ACTH ${ }^{1-39}$ (lot 24 249) (1:5000) was purchased from Immunonuclear Corporation (Stillwater, Minnesota). Horseradish peroxidase/rabbit anti-horseradish peroxidase complex (PAP) and goat anti-rabbit IgG were purchased from Cappel Laboratories (Cochranville, Pennsylvania). The reaction substrate used in the present experiment was 3,3'-diaminobenzidine tetrahydrochloride monohydrate (DAB) purchased from Aldrich Chemicals Co., Inc. (Milwaukee, Wisconsin). Since both the DAB and the acrolein constitute serious biohazards these chemicals were only handled under a fume hood while wearing protective gloves and clothing.

Immunocytochemical controls. The following controls were employed to ensure specificity in the immunocytochemical procedure: (1) dilution of antiserum until staining no longer occurred; (2) substitution of $1 \%$ normal goat serum for the 1st, 2nd or 3rd antibody; (3) omission of $\mathrm{H}_{2} \mathrm{O}_{2}$ from reaction; (4) substitution of pre-immune serum for the primary antibody. Primary antibodies were also absorbed with various concentrations of the relevant antigen before use.

Electron microscopy. For electron microscopic study of mitosis in the various cell types, dividing cells were first located in azure II-stained sections of pituitary glands. The blocks were 
Etching-sat. soln $\mathrm{NaOH}$ in absolute ethanol diluted 1:1 with absolute ethanol immediately before

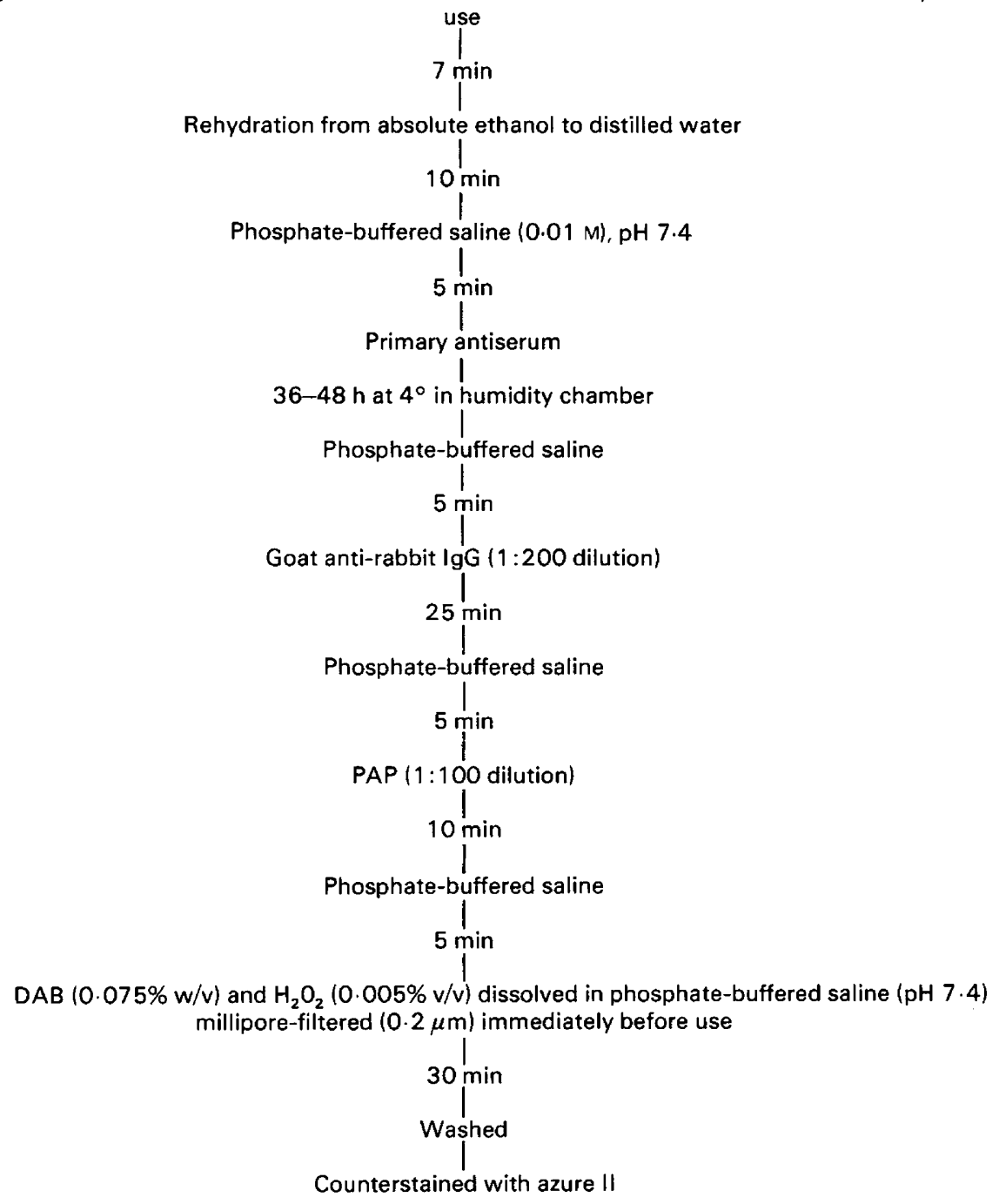

Text-fig. 1. Flow diagram of technique for immunocytochemical staining.

retrimmed and $0.5 \mu \mathrm{m}$ semi-thin sections were mounted on glass slides for immunocytochemical staining while adjacent thin sections were collected on 200-mesh nickel grids and stained with uranyl acetate followed by lead citrate. This permitted determination of both the immunoreactive hormone content and the ultrastructural features of any given dividing cell.

Analysis of data. Sections were examined at $\times 1000$ on a Leitz Orthoplan microscope. Mitotic figures were first counted on azure II-stained sections and then located on adjacent immunocytochemically stained sections to determine their immunoreactive content. Electron micrographs of dividing cells were taken on a Philips EM 300. Measurement of granule size in dividing cells was done on micrographs printed to a final magnification of $\times 64000$. Immunoreactive hormone content of dividing cells was recorded by locating these cells on the adjacent semi-thin immunocytochemically stained sections. Statistical comparisons of the number of dividing cells in control and ovariectomized animals was made with Student's $t$ test. 


\section{Results}

Mitotic figures were rare on sections from control animals with a mean of $0.223 \pm 0.043$ (mean \pm s.e.m.) mitotic figures per $1 \mathrm{~mm}^{2}$. In contrast, sections from pituitaries of ovariectomized animals had as many as 28 mitotic figures on a section with a mean value of $3.56 \pm 0.286 / \mathrm{mm}^{2}(P<$ 0.001 ). While dividing somatotrophs, lactotrophs and non-immunoreactive cells were observed in control pituitaries, no examples of gonadotrophs or thyrotrophs undergoing division were found in these animals. In contrast a majority of the mitotic figures found in sections from ovariectomized animals were immunoreactive for gonadotrophins (see Table 1). These cells were always stained with both of the gonadotrophin antisera. The increased number of mitotic figures seen in ovariectomized rats was also due to a large increase in the number of dividing cells which did not stain with any of the antisera employed. Lactotrophs made up a small part of the total mitotic activity in these rats and only one example of a dividing thyrotroph was found; this latter cell also stained with the gonadotrophin antisera.

Table 1. Immunoreactivity of cells undergoing mitosis in pituitaries of rats killed 14 days after ovariectomy

\begin{tabular}{ccccccc}
\hline $\begin{array}{c}\text { Bovine } \\
\text { GH }\end{array}$ & $\begin{array}{c}\text { Rat } \\
\text { LH } \beta\end{array}$ & $\begin{array}{c}\text { Human } \\
\text { FSH } \beta\end{array}$ & $\begin{array}{c}\text { Rat } \\
\text { TSH } \beta\end{array}$ & $\begin{array}{c}\text { Porcine } \\
\text { ACTH }\end{array}$ & $\begin{array}{c}\text { Rat } \\
\text { prolactin }\end{array}$ & \%* \\
\hline- & + & + & - & - & - & $54 \cdot 5$ \\
- & + & + & + & - & - & $<1$ \\
- & - & - & - & - & + & $<1$ \\
+ & - & - & - & - & - & $8 \cdot 5$ \\
- & - & - & - & - & - & 35.7 \\
\hline
\end{tabular}

* Of total no. of dividing cells in section.

All of the dividing immunoreactive gonadotrophs were large ovoid cells situated adjacent to blood capillaries. In azure II-stained sections these cells exhibited a homogeneously stained cytoplasm varying from dark blue to nearly unstained. Negative images of large Golgi rings were commonly seen. In electron micrographs, plentiful dilated sacs of rough endoplasmic reticulum gave these cells a mottled appearance typical of many non-dividing gonadotrophs seen in the same sections. Granules (mean diameter $200 \mathrm{~nm}$ ) were present in these cells in various quantities; some cells were only sparsely granulated whlle others contained extensive patches of granules (P1. 1, Fig. 3). The amount of granulation in these cells was directly correlated with the intensity of immunocytochemical staining seen in semi-thin sections of these cells (Pl. 1, Figs 1 and 2).

Dividing cells which did not stain with any of the antisera employed (Pl. 2, Figs 4-7) varied from unstained to light blue in azure 11 preparations and exhibited a wide range of shapes from angular to ovoid. Electron microscopy of several of these cells revealed a population of small granules (mean diam. $100 \mathrm{~nm}$ ) dispersed throughout the cytoplasm, although most were concentrated near the cell periphery (Pl. 2, Fig. 8). Many of these cells were adjacent to capillaries and surrounded by other granular cell types. Dividing immunoreactive somatotrophs were also observed. These cells were of two types. Most dividing somatotrophs were small, angular cells with dark blue cytoplasm in azure II-stained sections. However, a few were large ovoid cells with a pale blue cytoplasm containing patches of dark blue especially at the cell periphery. Both of these cell types contained large granules (mean diam. $275 \mathrm{~nm}$ ) with a homogeneous matrix. The cytoplasm of small, darkly staining somatotrophs was densely packed with granules while the large somatotrophs contained scattered patches of granules (Pl. 3, Figs 9-14). 


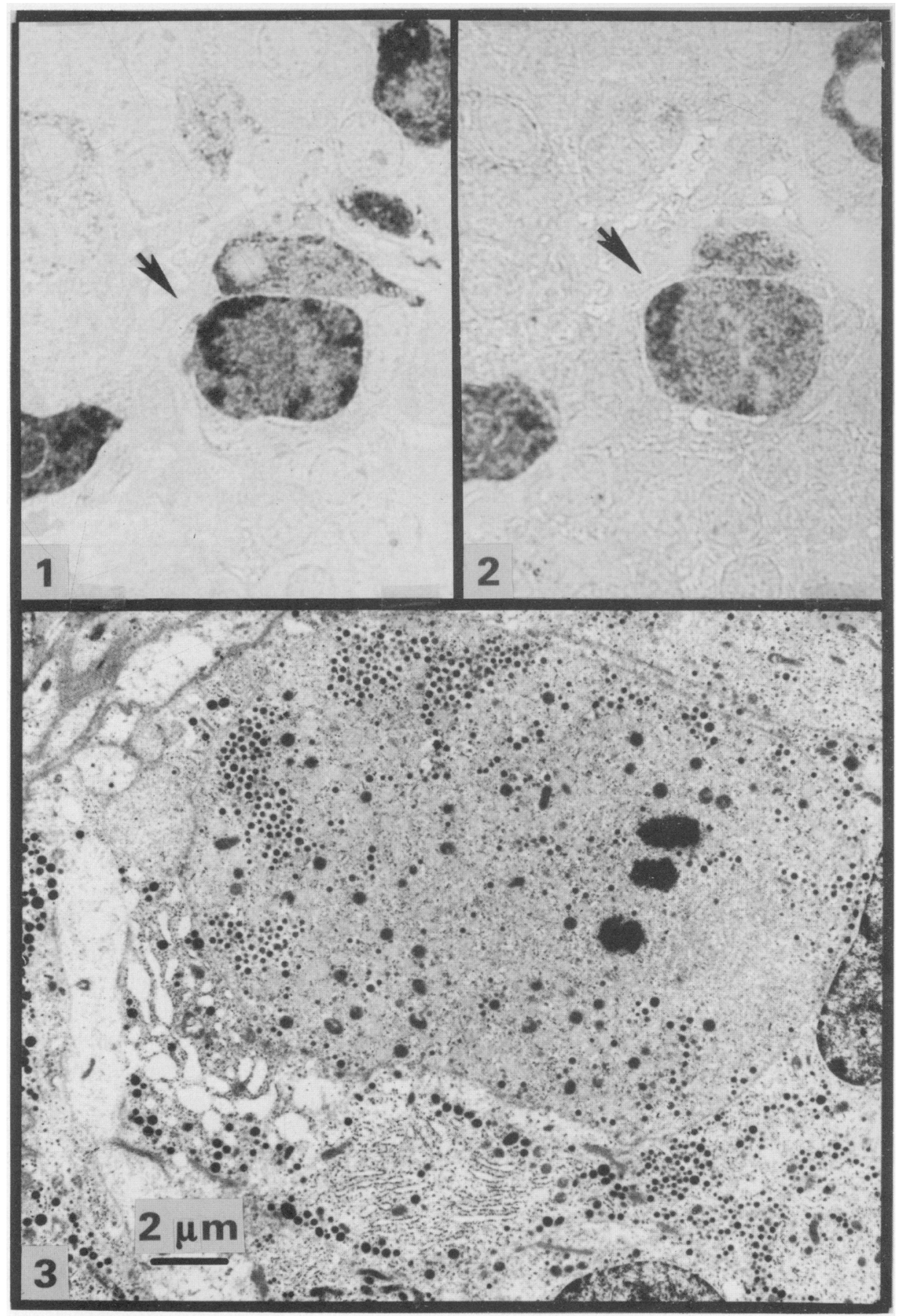

Dividing immunoreactive gonadotroph.

Fig. 1. Section stained with anti-human FSH $\beta$ (arrow indicates dividing cell). $\times 1520$.

Fig. 2. Section stained with anti-rat LH $\beta . \times 1520$.

Fig. 3. Electron micrograph of the cell arrowed in Figs 1 and 2. Areas of granule accumulation correspond to areas of dark staining in light micrographs. Uranyl acetate/lead citrate. 
PLATE 2

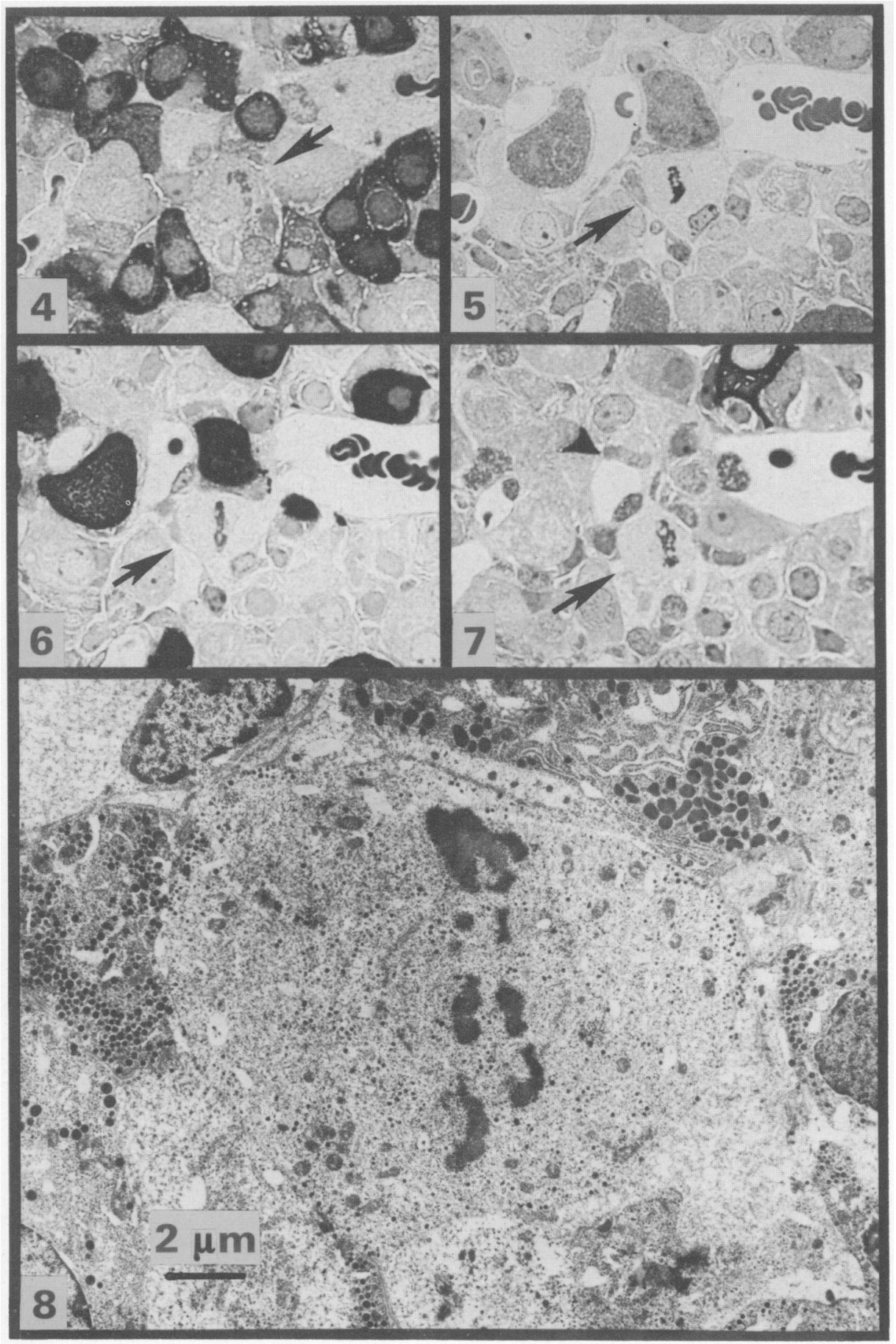

Dividing non-immunoreactive cell.

Fig. 4. Anti-bovine GH. $\times 750$.

Fig. 5. Anti-human FSH $\beta . \times 750$.

Fig. 6. Anti-rat LH $\beta . \times 750$.

Fig. 7. Anti-porcine ACTH. $\times 750$.

Fig. 8. Electron micrograph of cell arrowed in Figs $4-7$ showing the population of small granules dispersed throughout cytoplasm. Uranyl acetate/lead cierale. from Bioscientifica.com at 04/26/2023 02:02:36AM 


\section{PLATE 3}
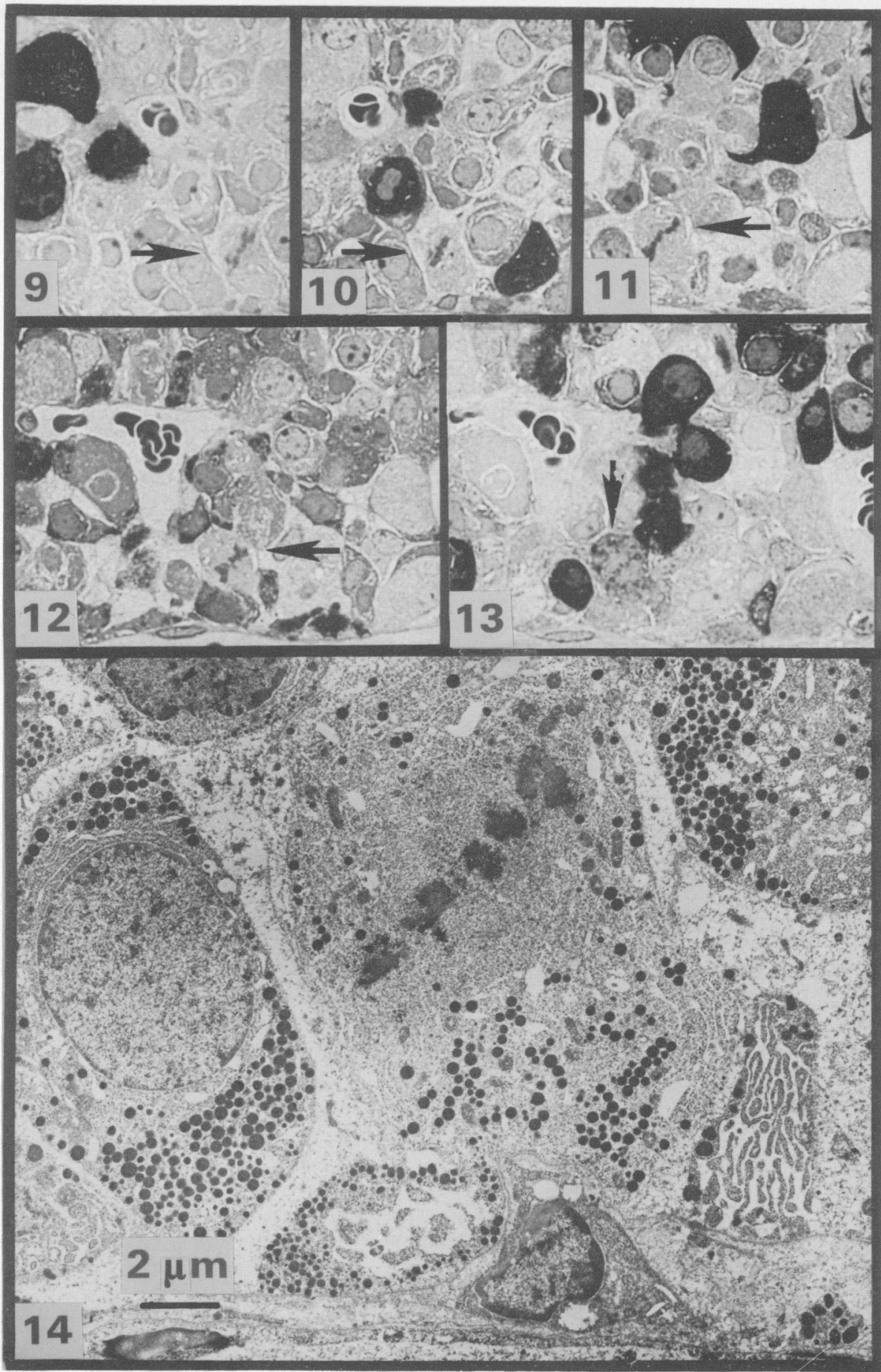

Dividing immunoreactive somatotroph.

Fig. 9. Anti-rat LH $\beta . \times 750$.

Fig. 10. Anti-rat TSH $\beta . \times 750$.

Fig. 11. Anti-porcine ACTH. $\times 750$.

Fig. 12. Anti-rat prolactin. $\times 750$.

Fig. 13. Anti-bovine GH. $\times 750$.

Fig. 14. Electron micrograph of cell arrowed in Figs $9-13$; the dividing cell is between two small $02: 02: 36 \mathrm{AM}$ angular somatotrophs. Uranyl acetate/lead citrate. 


\section{Discussion}

The extremely low number of mitotic figures counted in the control animal pituitaries may be due in part to the stage of the oestrous cycle at death; dioestrus has been shown to be the period of lowest mitotic activity in the mature rat (Hunt \& Hunt, 1966). Furthermore, the time of death $(10: 00-11: 00 \mathrm{~h})$, may have been a contributing factor in the scarcity of mitotic figures observed. In the male rat (Nouet \& Kujas, 1975) mitotic activity is low at 10:00 h although at $11: 00 \mathrm{~h}$ the number of mitotic figures is increased. In intact animals we found no dividing cells immunoreactive for LH or FSH. This is in agreement with the results of Hunt \& Hunt (1966) who, although reporting high mitotic rates at various stages of the oestrous cycle in rats, found no labelled nuclei from basophils: the labelled cells that they observed were either unstained or very lightly stained with PAS.

Our data indicate that an increase in overall mitotic activity occurred after ovariectomy. This is in contrast to early work by Pomerat (1941) who demonstrated a decrease in total number of mitotic figures after castration in male rats. However, Hymer et al. (1970) found a significant increase in DNA synthesis 14 days after castration in male rats. Both investigations demonstrated an increase in mitotic activity in pituitary basophils after gonadectomy, which supports our finding of a substantial increase in mitotic activity among gonadotrophs. While other investigators have reported that a majority of mitotic divisions of anterior pituitary gland cells occur in chromophobes (up to $80 \%$ of dividing cells), cell classification was made on the basis of tinctorial staining properties (Pomerat, 1941; Hunt \& Hunt, 1966; Hymer et al., 1970) or electron microscopy (Hymer et al., 1970). Since some of the dividing immunoreactive gonadotrophs examined in our study contained very few granules, identification of these cells would have been more difficult without positive gonadotrophin-immunoreactivity. That some of the dividing non-immunoreactive cells examined in the present study contained granules raises some question as to their identification. These granules may contain a hormone modified in some way such that it is not recognizable by the antisera employed. Another possibility is that these granules contained a hormone other than those for which we had specific antisera.

Every dividing gonadotroph that we examined was stained with both of the antigonadotrophin sera. Furthermore, only one of 141 dividing gonadotrophs stained with antiserum to TSH $\beta$. Extensive examination of sections stained with antiserum to TSH $\beta$ revealed no other dividing cells, but it is possible that this cell was undergoing transformation from a thyrotroph to a gonadotroph (Yoshimura, Nogami, Shirasawa \& Yashiro, 1981) at the time of division. No other combinations of hormones were found in any dividing cells which were examined.

From our electron microscopic observations it is apparent that mitosis in gonadotrophs after ovariectomy occurs almost exclusively in large, ovoid cells with highly vesiculated rough endoplasmic reticulum and a single population of granules similar in description to the type IV basophil of Yoshimura et al. (1977), even though this cell type makes up only a part of the total post-ovariectomy gonadotroph population.

We thank Dr A. F. Parlow and NIAMDD for antisera against $\operatorname{rLH} \beta$, hFSH $\beta$, rat prolactin and rTSH $\beta$ and Dr Peter Petrusz, University of North Carolina, for antiserum against bGH. The work was supported by PHS grant HD12173, Diabetes grant AM22125 and Research Career Development Award HD00243 (D.A.K.).

\section{References}

Baskin, D.G., Erlandsen, S.L. \& Parsons, J.A. (1979) Immunocytochemistry with osmium-fixed tissue. Light microscopic localization of growth hormone and prolactin with the unlabelled antibody-enzyme method. J. Histochem. Cytochem. 27, 867-872.
Hunt, T.E. \& Hunt, E.A. (1966) A radiographic study of the proliferative activity of adrenocortical and hypophyseal cells of the rat at different periods of the estrous cycle. Anat. Rec. 156, 361-367.

Hymer, W.C., Mastro, A. \& Griswold, E. (1970) DNA 
synthesis in the anterior pituitary of the male rat: effect of castration and photoperiod. Science, N.Y. 167, 1629-1631.

Ishikawa, H. \& Totsuka, S. (1968) Histological and histometrical studies on the adenohypophyseal cells in castrated male rats, with special emphasis on a contradiction of classifying the gonadotroph and the thyrotroph. Endocr. jap. 15, 457-479.

Kunert-Radek, J. \& Pawlikowski, M. (1975) The effect of thyrotropin releasing hormone on cell proliferation in the anterior pituitary gland of thyroidectomized rats. Neuroendocrinology 17, 92-95.

Kurosumi, K. (1971) Mitosis of the rat anterior pituitary cells. An electron microscope study. Arch. Histol. Jpn. 33, 145-160.

Kurosumi, K. \& Oota, Y. (1968) Electron microscopy of two types of gonadotrophs in the anterior pituitary glands of persistent estrous and diestrous rats. $Z$. Zellforsch. mikrosk. Anat. 85, 34-46.

Mason, T.E., Phifer, R.F., Spicer, S.S., Swallow, R.A. \& Dreskin, R.B. (1969) An immunoglobulin-enzyme bridge method for localizing tissue antigens. $J$. Histochem. Cytochem. 17, 159-166.

Moriarty, G.C. \& Garner, L.L. (1977) Immunocytochemical studies of cells in the rat adenohypophysis containing both ACTH and FSH. Nature, Lond. 265, 356-358.

Nouet, J.C. \& Kujas, M. (1975) Variations of mitotic activity in the adenohypophysis of male rats during a 24-hour cycle. Cell Tissue Res. 164, 193-200.

Pomerat, G.R. (1941) Mitotic activity in the pituitary of the white rat following castration. Am. J. Anat. 69, 89-117.

Stadtler, F., Stöcker, E., Dhom, G. \& Tietze, H.U. (1970) Autoradiographic studies on nuclear DNA and RNA synthesis in the adenohypophysis of castrated rats. Acta endocr., Copenh. 64, 324-338.

Yoshimura, F. \& Harumiya, K. (1965) Electron microscopy of the anterior lobe of pituitary in normal and castrated rats. Endocr. jap. 12, 119-152.

Yoshimura, F., Soji, T., Kumagai, T. \& Yokoyama, M. (1977) Secretory cycle of the pituitary basophils and its morphological evidence. Endocr. jap. 24, 185202.

Yoshimura, F., Nogami, H., Shirasawa, N. \& Yashiro, T. (1981) A whole range of fine structural criteria for immunohistochemically identified LH cells in rats. Cell Tissue Res. 217, 1-10.

Received 30 March 1982 